\title{
Antibacterial activity of Brazilian Northeast plants against Corynebacterium
}

\section{pseudotuberculosis}

\author{
Atividade antibacteriana de plantas do Nordeste brasileiro contra Corynebacterium \\ pseudotuberculosis \\ Actividad antibacteriana de plantas del Noreste brasileño contra Corynebacterium \\ pseudotuberculosis
}

Received: 08/26/2021 | Reviewed: 09/04/2021 | Accept: 09/06/2021 | Published: 09/07/2021

\author{
Maria Emilia Alcantara \\ ORCID: https://orcid.org/0000-0002-8197-3415 \\ Federal University of Bahia, Brazil \\ E-mail: maria.schinoni10@gmail.com \\ Antonio Pedro Fróes de Farias \\ ORCID: https://orcid.org/0000-0002-2625-9470 \\ Federal University of Bahia, Brazil \\ E-mail: froes_pedro@hotmail.com \\ Maria da Conceição Aquino de Sá \\ ORCID: https://orcid.org/0000-0001-8145-7018 \\ Federal University of Bahia, Brazil \\ E-mail: ceicazoo@hotmail.com \\ Soraya Castro Trindade \\ ORCID: https://orcid.org/0000-0001-7125-9114 \\ Federal University of Bahia, Brazil \\ E-mail: soraya@uefs.br \\ Roberto Meyer \\ ORCID: https://orcid.org/0000-0002-4727-4805 \\ Federal University of Bahia, Brazil \\ E-mail: rmeyer@ufba.br \\ José Tadeu Raynal Rocha Filho \\ ORCID: https://orcid.org/0000-0002-2771-0235 \\ Federal University of Bahia, Brazil \\ E-mail: jtraynal@hotmail.com
}

\begin{abstract}
The production of small ruminants is an important economic activity of the brazilian Northeast, but some diseases have a high prevalence in this region, such as caseous lymphadenitis (CL), caused by Corynebacterium pseudotuberculosis. The treatment of CL is often ineffective, which justifies the search of new active principles from plants, mainly of the region, to have an accessible treatment. For this reason, the present study was carried out to evaluate the in vitro antibacterial activity of Annona squamosa, Azadirachta indica, Allium sativum, Prosopis juliflora and Portulaca oleracea against $C$. pseudotuberculosis. Agar well diffusion assay (AWD) and broth microdilution - to determine minimum inhibitory concentration (MIC) and bactericidal concentration (MBC) - evaluated the antimicrobial activity. The highest antibacterial potential was obtained by ethanolic extracts of $A$. indica leaf (MIC $0,12 \mathrm{mg} / \mathrm{mL}$ for 2 strains), A. squamosa stalk (MIC $0,55 \mathrm{mg} / \mathrm{mL}$ for 3 strains) and shell (MIC $0,6 \mathrm{mg} / \mathrm{mL}$ for 3 strains). These extracts also presented the highest inhibition zone in AWD $(30 \mathrm{~mm}, 38 \mathrm{~mm}$ and $32 \mathrm{~mm}$, respectively). A. squamosa and A. indica have high antimicrobial potential against C. pseudotuberculosis.
\end{abstract}

Keywords: Caseous lymphadenitis; Phytotherapy; Semiarid.

\section{Resumo}

A produção de pequenos ruminantes é uma atividade econômica importante do Nordeste brasileiro, porém algumas doenças possuem alta prevalência nessa região, como a linfadenite caseosa (LC), causada por Corynebacterium pseudotuberculosis. O tratamento da LC frequentemente é ineficaz, o que justifica a procura de novos princípios ativos de plantas, principalmente oriundos da região, para um tratamento acessível. Assim, o presente estudo foi realizado para avaliar a atividade antibacteriana in vitro de Annona squamosa, Azadirachta indica, Allium sativum, Prosopis juliflora e Portulaca oleracea contra C. pseudotuberculosis. Testes de difusão em ágar por poço (DAP) e microdiluição em caldo - para determinar concentração inibitória mínima (CIM) e bactericida mínima (CBM) - avaliaram a atividade antimicrobiana. O maior potencial antibacteriano foi obtido pelos extratos etanólicos da folha de A. indica (CIM 0,12 
$\mathrm{mg} / \mathrm{mL}$ contra 2 cepas), caule de A. squamosa (CIM 0,55 mg/mL contra as 3 cepas) e casca de A. squamosa (CIM 0,6 $\mathrm{mg} / \mathrm{mL}$ contra as 3 cepas). Esses extratos também apresentaram a maior zona de inibição no teste DAP (30 mm, $38 \mathrm{~mm}$ e $32 \mathrm{~mm}$, respectivamente). A. squamosa e A. indica possuem alto potencial antimicrobiano contra $C$. pseudotuberculosis.

Palavras-chave: Linfadenite caseosa; Fitoterapia; Semiárido.

\section{Resumen}

La producción de pequeños rumiantes es una actividad económica importante del Noreste brasileño, a pesar de que algunas enfermedades tienen alta prevalencia en esa región, como la linfadenitis caseosa (LC), causada por Corynebacterium pseudotuberculosis. El tratamiento de la LC frecuentemente es ineficaz, lo que justifica la busca de nuevos principios activos de plantas, principalmente de la región, para un tratamiento accesible. Así, este estudio fue hecho para evaluar la actividad antibacteriana in vitro de Annona squamosa, Azadirachta indica, Allium sativum, Prosopis juliflora y Portulaca oleracea contra C. pseudotuberculosis. Pruebas de difusión en agar método pozo (DAP) y microdilucion en caldo - para determinar la concentración inhibitoria mínima (CIM) y bactericida mínima (CBM) evaluaron la actividad antimicrobiana. El mayor potencial antibacteriano fue obtenido por los extractos etanólicos de hoja de A. indica (CIM 0,12 mg/mL contra 2 cepas), tallo de A. squamosa (CIM 0,55 mg/mL contra las 3 cepas) y cáscara de $A$. squamosa (MIC $0,6 \mathrm{mg} / \mathrm{mL}$ contra las 3 cepas). Esos extractos también presentaron la mayor zona de inhibición en la prueba DAP (30 mm, $38 \mathrm{~mm}$ y $32 \mathrm{~mm}$, respectivamente). A. squamosa y A. indica tienen grande potencial antimicrobiano contra C. pseudotuberculosis.

Palabras clave: Linfadenitis caseosa; Fitoterapia; Semi árido.

\section{Introduction}

The production of small ruminants in the Brazilian Northeast is a very important socio-economic activity, and more than $92 \%$ of goats and $65 \%$ of sheep of Brazil are in this region (Magalhães, Martins, Holanda \& Lucena, 2018). Generally, this production is based on the extensive system, which results in low sanitary and technological investment. This allows the presence of diseases in the herds, and the one with higher prevalence at Brazilian semiarid is caseous lymphadenitis (CL) (Alves, Santiago \& Pinheiro, 2007).

CL is an infectious chronic disease and highly contagious, caused by Corynebacterium pseudotuberculosis, and generates granulomas in external and internal lymph nodes, and can spread through the viscera, which entails economic losses due to the devaluation of meat, skin, milk, and wool (Carminati et al., 2003). Diagnosis often occurs at the later stage of the CL, when the clinical signs are apparent, so, the treatment is generally not effective, which justifies research to discover new therapeutic molecules (Galvão et al., 2017).

The use of medicinal plants is a cosmopolitan practice and the constant studies of phytotherapeutic agents are a good methodology to discover new drugs, especially in tropical regions with abundant biodiversity, for example, Brazil (Araujo et al., 2014). Due to the indiscriminate use of antibiotics, several bacteria have developed mechanisms of resistance to most of the antibiotics, so, it is necessary to find new active principles (Silva, Antunes \& Catão, 2011).

Natural antibiotics are extracted from medicinal plants and generally have a broad spectrum, besides having a greater molecular diversity than the synthetic compounds (Delfani, Bahmani, Mohammadrezaei-Khorramabadi \& Rafieian-Kopaei, 2017). Several studies have already shown the positive effects on the use of these natural substances, and with the publication of these beneficial factors, the study of plants becomes more present in laboratories routine (Fasihzadeh, Lorigooini \& Jivad, 2016; Samani et al., 2016).

Researches have shown several medicinal effects of Annona squamosa, and have clarified that their flavonoids have antibiotic action (Kotkar et al., 2001). Of all the compounds already discovered by Azadirachta indica, 45\% are part of the triterpenoids, which has a proven antimicrobial, antitumor, and anti-inflammatory potential (Chen et al., 2018).

Allium sativum has as main compound allicin, which is responsible for its high antibiotic potential, as well as antifungal, antiviral and antiparasitic (Johnson, Olaleye \& Kolawole, 2016). The therapeutic properties of Prosopis juliflora tree have already been demonstrated in a variety of in vitro studies, including antimicrobial, anti-inflammatory and antifungal activity 
(Nagalakshmi \& Anuradha, 2017). Research has proven the antioxidant, antibacterial, analgesic and healing effects of Portulaca oleracea, and is listed by the World Health Organization (WHO) as one of the most used herbal plants (Iranshahy et al., 2017; Peng et al., 2015).

The use of plants with antimicrobial potential and present in Brazilian Northeast to combat CL can establish a new treatment with better efficiency and accessibility. For this reason, the aim of this study was to evaluate the in vitro antimicrobial activity of Annona squamosa, Azadirachta indica, Allium sativum, Prosopis juliflora, and Portulaca oleracea, against C. pseudotuberculosis.

\section{Material and Methods}

This is a laboratory research developed under controlled conditions with quantitative approach. It was based on experiments with defined methodologies on the antimicrobial effect of plant extracts against C. pseudotuberculosis (Pereira, Shitsuka, Parreira \& Shitsuka, 2018).

\subsection{Plant materials and extraction}

The extraction process was based on the methodology of Benfatti, Cordova, Guedes, Magina and Cordova (2010), with modifications. Plant samples were oven-dried $\left(40{ }^{\circ} \mathrm{C}-72 \mathrm{~h}\right)$, triturated and macerated in $95 \%$ ethanol with subsequent passage through filter and concentration in rotary evaporation under reduced pressure $\left(60^{\circ} \mathrm{C}\right)$ until total alcohol removal. The samples were dissolved in $10 \%$ DMSO with shaking (48 h), and the fraction which after that period did not solubilize, was separated into new Eppendorf and dissolved in $70 \%$ ethanol with shaking $(48 \mathrm{~h})$.

The selected parts of the different plants for the preparation of extracts and the final concentration of the fractions are shown in Table 1.

Table 1. Selected parts of each plant for preparation of extracts and final concentration in both fractions (ethanolic and DMSO).

\begin{tabular}{cccc} 
Extract & & \multicolumn{2}{c}{ Concentration $(\mathbf{m g} / \mathbf{m L})$} \\
\cline { 3 - 4 } & & Ethanol 70\% & DMSO 10\% \\
\cline { 3 - 4 } Annona squamosa & Stems & 142,8 & 104,7 \\
& Seed & 44,2 & 36,5 \\
& Shell & 144,5 & 113,2 \\
& Leaf & 110,9 & 54,3 \\
\hline \multirow{2}{*}{ Allium sativum } & Bulb & - & 1301,0 \\
\hline \multirow{2}{*}{ Azadirachta indica } & Stems & 96,3 & 13,9 \\
& Leaf & 31,3 & 33,1 \\
\hline \multirow{2}{*}{ Prosopis juliflora } & Pods & 97,2 & 165,6 \\
Portulaca oleracea & Leaf & 70,2 & 10,5 \\
\hline
\end{tabular}

Source: Authors.

\subsection{Bacterial strains and growth conditions}

It was selected three C. pseudotuberculosis isolates, the 76 strain (CAPJ4) - strong biofilm producer - and the 21 strain (CAP3W) - non-biofilm producer - deposited in the GenBank under accession number CP026499 and CP026500, respectively. Also, it was selected the VD57 strain, deposited in the GenBank under the accession number CP009927. The inoculum was prepared through the transfer of five C. pseudotuberculosis colonies - cultivated in Petri dishes with Brain Heart Infusion agar 
(BHI, Sigma-Aldrich, St. Louis, USA) - to $5 \mathrm{~mL}$ of sterile saline solution $0,9 \%$. After this was measured in a spectrophotometer $(600 \mathrm{~nm})$ and adjusted to achieve optical density between 0,08 e $0,1\left(\sim 1,5 \times 10^{8} \mathrm{UFC} / \mathrm{mL}\right)$.

\subsection{Antimicrobial sensitivity test}

For agar well diffusion assay (AWD) Petri dishes (60x15 mm) were prepared with BHI agar $(25 \mathrm{~mL})$ with 4 equidistant holes $(6 \mathrm{~mm} \varnothing)$. The inoculum $\left(\sim 1,5 \times 10^{8} \mathrm{UFC} / \mathrm{mL}\right)$ was seeded with swab all over the surface and the wells were filled with 20 $\mu \mathrm{L}$ of each extract. The control was ethanol 70\%, DMSO 10\% and antibiotic (Streptomycin $1 \mathrm{mg} / \mathrm{mL}+\mathrm{Penicillin}-1000$ units $/ \mathrm{mL})$. The plates were incubated at $37^{\circ} \mathrm{C}(48 \mathrm{~h})$, and the inhibition zone was measured in millimeters. The analysis of the results followed the CLSI (2018) recommendations with adaptations.

Broth microdilution was performed according to Santos et al. (2019) with modifications, to determine Minimum Inhibitory Concentration (MIC) and Minimum Bactericidal Concentration (MBC). 96 well polystyrene plates were used, and in line A was added $50 \mu \mathrm{L}$ of extract and $50 \mu \mathrm{L}$ of BHI broth (2x concentrated) and in the remaining lines was added $50 \mu \mathrm{L}$ BHI broth ( $2 \mathrm{x}$ concentrated). It was homogenized with micropipette the wells of line A and subsequent passage of $50 \mu \mathrm{L}$ to the wells of line B, repeating the procedure until line H. Subsequently, $50 \mu \mathrm{L}$ of inoculum $\left(\sim 1,5 \times 10^{8} \mathrm{UFC} / \mathrm{mL}\right)$ was added to the whole plate. The same control of AWD assay was made. The plates were incubated at $37{ }^{\circ} \mathrm{C}(48 \mathrm{~h})$ and thereafter was measured in a spectrophotometer $(595 \mathrm{~nm})$ for MIC determination. $10 \mu \mathrm{L}$ of each well was pipetted with a multichannel micropipette and using the tips, perforations were made in Petri dishes with BHI agar $(25 \mathrm{~mL})$. The plates were incubated at $37{ }^{\circ} \mathrm{C}(48 \mathrm{~h})$, and it was made the visualization in the colony counter for MBC determination.

\subsection{Statistical analysis}

The results obtained in the AWD assays were submitted to analysis of variance (ANOVA) and it was used as a posttest of multiple-comparison the Tukey's test, with a significance of 5\%. Statistical analyses were performed using GraphPad Prism v. 7.05 .

\section{Results and Discussion}

The results of antimicrobial activity of plant extracts against different strains of Corynebacterium pseudotuberculosis are shown in Tables 2 and 3 .

The parts of A. squamosa obtained distinct results in the antibacterial action. Although the ethanolic fraction of $A$. squamosa seed has an effect against 21 strain (MIC and MBC $22 \mathrm{mg} / \mathrm{mL}$ ) and VD57 strain (MIC and MBC $11 \mathrm{mg} / \mathrm{mL}$ ), the concentrations were high, besides that the DMSO fraction of this extract had no antibacterial effect (Table 2). In opposition to the seed, the other parts of $A$. squamosa in an ethanolic solvent, demonstrated a satisfactory effect on the tested strains. The stalk had the same MBC for the 3 strains $(0,55 \mathrm{mg} / \mathrm{mL})$ and the shell presented the lowest MBC against 21 and VD57 strains $(0,6$ $\mathrm{mg} / \mathrm{mL})$, while the leaf had the best MBC against VD57 strain $(3,5 \mathrm{mg} / \mathrm{mL})$. This result corroborates a study that demonstrated that while the methanolic extract of A. squamosa seed had no antimicrobial activity against Staphylococcus aureus, Klebsiella pneumoniae and Enterococcus faecalis, the extract of A. squamosa leaf was effective against these bacteria (Pinto et al., 2017). The difference between the parts of A. squamosa is also verified in AWD assay (Table 3), in which, against VD57 strain the ethanolic extract of stalk, shell, and leaf of A. squamosa presented inhibition zone of $38 \mathrm{~mm}, 32 \mathrm{~mm}$ e $25 \mathrm{~mm}$, respectively, which had no statistical difference with the antibiotic, while the A. squamosa seed had no inhibition zone.

A. sativum has no antimicrobial activity on any of the tested strains (Table 2 and 3), that is the opposite of studies that demonstrated the effect of A. sativum against Staphylococcus aureus (Najafi et al., 2016), Aeromonas hydrophila (Masoumzadeh 
et al., 2017), and Pseudomonas aeruginosa (Johnson, Olaleye \& Kolawole, 2016). However, studies have demonstrated that the aqueous A. sativum extract has a higher antibacterial activity potential, thus, the use of DMSO solvent in this study may have interfered with the extraction of active components (Chen et al., 2018; Saha, Saha, Hossain \& Paul, 2015).

Table 2. Minimum inhibitory concentration (MIC) and minimum bactericidal concentration (MBC) in $\mathrm{mg} / \mathrm{mL}$ of selected extracts against three $C$. pseudotuberculosis strains.

\begin{tabular}{|c|c|c|c|c|c|c|c|c|}
\hline \multirow{3}{*}{ Diluent } & \multirow{3}{*}{ Species extrac } & & \multicolumn{6}{|c|}{ Strain C.pseudotuberculosis } \\
\hline & & & \multicolumn{2}{|c|}{ VD57 } & \multicolumn{2}{|c|}{21} & \multicolumn{2}{|c|}{76} \\
\hline & & & MIC & MBC & MIC & $\mathrm{MBC}$ & MIC & $\mathrm{MBC}$ \\
\hline \multirow{9}{*}{ DMSO 10\% } & \multirow{4}{*}{ Annona squamosa } & Stalk & - & - & - & - & - & - \\
\hline & & Seed & - & - & - & - & - & - \\
\hline & & Shell & - & - & 56 & - & 56 & 56 \\
\hline & & Leaf & - & - & - & - & 27 & - \\
\hline & Allium sativum & Bulb & - & - & - & - & - & - \\
\hline & \multirow{2}{*}{ Azadirachta indica } & Stalk & 1,7 & 7 & - & - & - & - \\
\hline & & Leaf & 16 & 16 & 8 & - & 16 & - \\
\hline & Prosopis juliflora & Pods & 1,3 & 1,3 & 5 & 10 & 5 & 20 \\
\hline & Portulaca oleracea & Leaf & 5 & 5 & - & - & 5 & - \\
\hline \multirow{7}{*}{ Ethanol 70\% } & \multirow{4}{*}{ Annona squamosa } & Stalk & 0,55 & 0,55 & 0,55 & 0,55 & 0,55 & 0,55 \\
\hline & & Seed & 11 & 11 & 22 & 22 & - & - \\
\hline & & Shell & 0,6 & 0,6 & 0,6 & 0,6 & 0,6 & 1,1 \\
\hline & & Leaf & 1,7 & 3,5 & 3,5 & 7 & 14 & 14 \\
\hline & Azadirachta indica & Leaf & 0,12 & 0,25 & 0,12 & 0,25 & 0,5 & 2 \\
\hline & Prosopis juliflora & Pods & 6 & 24 & 0,4 & 0,4 & 1,5 & 3 \\
\hline & Portulaca oleracea & Leaf & 4,4 & 17,5 & 2,2 & 4,4 & 4,4 & 8,7 \\
\hline \multirow{3}{*}{ Control } & DMSO $10 \%$ & & - & - & - & - & - & - \\
\hline & Ethanol $70 \%$ & & - & - & - & - & - & - \\
\hline & Antibiotic & & $<0,01$ & $<0,01$ & $<0,01$ & $<0,01$ & $<0,01$ & $<0,01$ \\
\hline
\end{tabular}

( - ) No MIC or MBC detection. Source: Authors.

Although both extracts of $A$. indica leaf demonstrate anti-Corynebacterium effect, the ethanolic fraction, which reached MIC of $0,12 \mathrm{mg} / \mathrm{mL}$ against VD57 and 21 strains, had more satisfactory results when compared to the extract in DMSO $10 \%$ (Table 1). A. indica leaf ethanol extract also presented satisfactory results in AWD assay, with inhibition zone of $30 \mathrm{~mm}$ (VD57 strain), $20 \mathrm{~mm}$ (21 strain) and $23 \mathrm{~mm}$ (76 strain), without significant statistical difference compared to the antibiotic, as shown in table 3.

The best antimicrobial action of ethanolic extract compared to DMSO was also observed in A. indica stalk, once in AWD assay, the ethanolic extract obtained inhibition zone $(16 \mathrm{~mm}, 17 \mathrm{~mm}$ e $25 \mathrm{~mm}$ against 21, 76 and VD57 strains, respectively), while DMSO extract had no antibacterial effect (Table 3). As in this study, Success et al. (2017) demonstrated that the ethanolic extract of $A$. indica stalks obtained the highest antibacterial activity against Proteus mirabilis, Proteus vulgaris, S. aureus, and Bacillus sp.

It is observed in Table 2 that $P$. juliflora presented antimicrobial activity in ethanolic extract (MBC against $21-0,4$ $\mathrm{mg} / \mathrm{mL}$ ) and in DMSO extract (MBC against VD57 - 1,3 mg/mL). Despite this, the ethanolic extract had superior antimicrobial activity, which corroborates with a study that indicated that ethanolic and aqueous extracts are better to concentrate active metabolites of P. juliflora (Khandelwal, Sharma \& Agrawal, 2016). Care should be taken with this plant because contains neurotoxic piperidine alkaloids (Silva, Silva, Silva \& Costa, 2018). 
The ethanolic extract of $P$. oleracea presented antimicrobial activity (Table 2) against all strains (MIC 2,2 $\mathrm{mg} / \mathrm{mL}$ to 21 and 4,4 mg/mL to VD57 and 76). The study of Peng et al. (2015) demonstrated that the ethanol extract of this plant was the most efficient against $S$. aureus, Streptococcus agalactiae and Streptococcus dysgalactiae from mastitis in cows.

Table 3. Inhibition zone (mm) in agar well diffusion assay (AWD) of selected extracts against three C. pseudotuberculosis strains.

\begin{tabular}{|c|c|c|c|c|c|}
\hline \multirow{2}{*}{ Diluent } & \multirow{2}{*}{\multicolumn{2}{|c|}{ Species extract }} & \multicolumn{3}{|c|}{ Strain C.pseudotuberculosis } \\
\hline & & & VD57 & 21 & 76 \\
\hline \multirow{9}{*}{ DMSO 10\% } & \multirow{4}{*}{ Annona squamosa } & Stalk & - & - & - \\
\hline & & Seed & - & - & 5 \\
\hline & & Shell & - & - & - \\
\hline & & Leaf & $13^{\mathrm{b}}$ & - & - \\
\hline & Allium sativum & Bulb & - & - & - \\
\hline & \multirow{2}{*}{ Azadirachta indica } & Stalk & $14^{\mathrm{b}}$ & - & - \\
\hline & & Leaf & - & - & - \\
\hline & Prosopis juliflora & Pods & $34^{\mathrm{a}}$ & $25^{\mathrm{a}}$ & $23^{\mathrm{a}}$ \\
\hline & Portulaca oleracea & Leaf & - & - & - \\
\hline \multirow{8}{*}{ Ethanol $70 \%$} & \multirow{4}{*}{ Annona squamosa } & Stalk & $38^{\mathrm{a}}$ & $19^{\mathrm{a}}$ & $20^{\mathrm{a}}$ \\
\hline & & Seed & - & - & - \\
\hline & & Shell & $32^{\mathrm{a}}$ & $15^{\mathrm{b}}$ & $18^{\mathrm{b}}$ \\
\hline & & Leaf & $25^{\mathrm{a}}$ & - & $14^{\mathrm{b}}$ \\
\hline & \multirow{2}{*}{ Azadirachta indica } & Stalk & $25^{\mathrm{a}}$ & $16^{\mathrm{b}}$ & $17^{\mathrm{b}}$ \\
\hline & & Leaf & $30^{\mathrm{a}}$ & $20^{\mathrm{a}}$ & $23^{\mathrm{a}}$ \\
\hline & Prosopis juliflora & Pods & $18^{\mathrm{a}}$ & $13^{\mathrm{b}}$ & $17^{\mathrm{b}}$ \\
\hline & Portulaca oleracea & Leaf & $10^{\mathrm{b}}$ & - & - \\
\hline \multirow{3}{*}{ Control } & DMSO $10 \%$ & & - & - & - \\
\hline & Ethanol $70 \%$ & & - & - & - \\
\hline & Antibiotic & & $48^{\mathrm{a}}$ & $50^{\mathrm{a}}$ & $55^{\mathrm{a}}$ \\
\hline
\end{tabular}

a,b Different letters on the same column indicate a statistically significant difference by the Tukey's test $(\mathrm{p}<0,05)$. ( - ) No zone of inhibition. Source: Authors.

In all methods of evaluation of antimicrobial activity, the ethanolic fraction showed a better anti-Corynebacterium potential when compared to DMSO (Table 2 and 3). This corroborates with studies that demonstrated that ethanol is superior when compared to solvents such as hexane, chloroform, ethyl acetate, butanol, and petroleum ether (Arya, Thakur \& Kashyap, 2012; Hossain \& Shah, 2015). Although some studies indicate that DMSO acts on cell membranes, this solvent did not interfere in the results of this study, once the control DMSO 10\% did not exert an antibacterial effect, as well as the control ethanol 70\% (Cheng, Song, Pas, Meijer \& Han, 2015). The antibiotic control presented superior antibacterial efficacy in both tests (Tables 2 and 3 ) because it has a high concentration of metabolites and the active principle is purified.

Strain 76 had a higher MBC mean $(13,2 \mathrm{mg} / \mathrm{mL})$ compared to the VD57 (7,9 mg/mL) and $21(5,6 \mathrm{mg} / \mathrm{mL}) \mathrm{strains}$, probably due to biofilm production that helps in agent survival under adverse conditions (McCarthy et al., 2015). Still, 8 extracts presented antibacterial effect against strain 76, like ethanolic fraction of A. squamosa leaf (MBC $14 \mathrm{mg} / \mathrm{mL}$ ), that is according to research of Pinto et al. (2017) in which the methanolic extract of A. squamosa leaf induced significant disruption of the biofilm of S. aureus and K. pneumonia. 


\section{Conclusion}

Seven extracts had antimicrobial activity against three strains - six ethanolic fractions (A. squamosa stalk, shell, and leaf; A. indica leaf; P. juliflora; P. oleracea) and one fraction in DMSO (P. juliflora). Thus, these phytotherapics have potential action against different strains of $C$. pseudotuberculosis, relevant for CL treatment, due to the variability of strains found in the herds. The extracts of A. squamosa, A. indica, and $P$. juliflora demonstrated higher antimicrobial potential against $C$. pseudotuberculosis.

Future researches to identify the components of these plants that demonstrated in vitro antimicrobial potential against C. pseudotuberculosis are important to understand the mechanisms of action of extracts and isolated compounds. In addition, studies in the animal model must be developed to evaluate the antibacterial activity in vivo and verify possible toxic effects.

\section{References}

Alves, F. S. F., Santiago, L. B., \& Pinheiro, R. R. (2007). Linfadenite Caseosa: o Estado da Arte. Documentos 74. Embrapa Caprinos.

Araujo, R. C. P., Neves, F. A. R., Formagio, A. S. N., Kassuya, C. A. L., Stefanello, M. E. A., Souza, V. V., Pavan, F. R., \& Croda, J. (2014). Evaluation of the anti-Mycobacterium tuberculosis activity and in vivo acute toxicity of Annona sylvatic. BMC Complement Altern Med, 14(209), 1-10.

Arya, V., Thakur, N., \& Kashyap, C. P. (2012). Preliminary phytochemical analysis of the extracts of Psidium leaves. J Pharmacogn Phytochem, 1(1), 1-5.

Benfatti, C. S., Cordova, S. M., Guedes, A., Magina, M. D. A., \& Cordova, C. M. M. (2010). Atividade antibacteriana in vitro de extratos brutos de espécies de Eugenia sp frente a cepas de molicutes. Rev Pan-Amaz Saude, 1(2), 33-39.

Carminati, R., Bahia, R., Moura Costa, L. F., Paule, B. J. A., Vale, V. L., Regis, L., Freire, S. M., Nascimento, I., Schaer, R., \& Meyer, R. (2003). Determinação da sensibilidade e da especificidade de um teste de ELISA indireto para o diagnóstico de linfadenite caseosa em caprinos. $R$ Ci Med Biol, 2(1), 88-93.

Chen, J., Fan, X., Zhu, J., Song, L., Li, Z., Lin, F., Yu, R., Xu, H., \& Zi, J. (2018). Limonoids from seeds of Azadirachta indica A. Juss. and their cytotoxic activity. Acta Pharm Sin B, 8(4), 639-644.

Cheng, C. Y., Song, J., Pas, J., Meijer, L. H. H., \& Han, S. (2015). DMSO induces dehydration near lipid membrane surfaces. Biophys J, 109(2), 330-339.

Clinical and Laboratory Standards Institute. (2018). Performance standards for antimicrobial disk susceptibility tests. (13nd ed.). CLSI standard M02. CLSI.

Delfani, S., Bahmani, M., Mohammadrezaei-Khorramabadi, R., \& Rafieian-Kopaei, M. (2017). Phytotherapy in Streptococcus agalactiae: An overview of the medicinal plants effective against Streptococcus agalactiae. J Clin Diagn Res, 11(6), 1-2.

Fasihzadeh, S., Lorigooini, Z., \& Jivad, N. (2016). Chemical constituents of Allium stipitatum regel (persian shallot) essential oil. Der Pharm Lett, 8(1), 175-80.

Galvão, C. E., Fragoso, S. P., Oliveira, C. E., Forner, O., Pereira, R. R. B., Soares, C. O., \& Rosinha, G. M. S. (2017). Identification of new Corynebacterium pseudotuberculosis antigens by immunoscreening of gene expression library. BMC Microbiol, 17(202), 1-8.

Hossain, M. A., \& Shah, M. D. (2015). A study on the total phenols content and antioxidant activity of essential oil and different solvent extracts of endemic plant Merremia borneensis. Arab J Chem, 8(1), 66-71.

Iranshahy, M., Javadi, B., Iranshahi, M., Jahanbakhsh, S. P., Mahyari, S., Hassani, F. V., \& Karimi, G. (2017). A review of traditional uses, phytochemistry and pharmacology of Portulaca oleracea L. J Ethnopharmacol, 205, 158-172.

Johnson, M., Olaleye, O. N., \& Kolawole, O. S. (2016). Antimicrobial and antioxidant properties of aqueous garlic (Allium sativum) extract against Staphylococcus aureus and Pseudomonas aeruginosa. Br Microbiol Res J, 14(1), 1-11.

Khandelwal, P., Sharma, R. A., \& Agrawal, M. (2016). Phytochemical analyses of various parts of Prosopis juliflora. Mintage J Pharm Med Sci, 5(1), 16-18.

Kotkar, H. M., Mendki, P. S., Sadan, S. V. G. S., Jha, S. R., Upasani, S. M., \& Maheshwari, V. L. (2001). Antimicrobial and pesticidal activity of partially purified flavonoids of Annona squamosa. Pest Manag Sci, 58, 33-37.

Magalhães, K. A., Martins, E. C., Holanda, Z. F. F., \& Lucena, C. C. (2018). Pesquisa Pecuária Municipal 2017: efetivo dos rebanhos caprinos e ovinos (No. 5). Sobral, CE: Embrapa Caprinos e Ovinos.

Masoumzadeh, M., Sharif, R. M., Shenavar, M. A., Alizadeh, M., Jalilpoor, J., \& Bazari, M. S. (2017). Study of antibacterial effects of garlic (Allium sativum) and Zataria multiflora extracts on Aeromonas hydrophila isolated of fish sturgeon. J Aquac Dev, 10(4), 125-132.

McCarthy, H., Rudkin, J. K., Black, N. S., Gallagher, L., O'Neill, E., \& O'Gara, J. P. (2015). Methicillin resistance and the biofilm phenotype in Staphylococcus aureus. Front Cell Infect Microbiol, 5(1), 1-9.

Nagalakshmi, G., \& Anuradha, R. (2017). FT-IR analysis and in vitro antibacterial activity of Prosopis juliflora. Eur J Pharm Med Res, 4(1), $322-326$. 
Najafi, F., Zangeneh, M. M., Tahvilian, R., Zangeneh, A., Amiri, H., Amiri, N., \& Moradi, R. (2016). In vitro antibacterial efficacy of essential oil of Allium sativum against Staphylococcus aureus. Int J Pharm Phytoc Res, 8(12), 2039-2043.

Peng, S., Dai, W., Yu, H., Wang, Y., Wang, X., \& Sun, S. (2015). Antibacterial activity of aqueous and ethanolic extracts of Portulaca oleracea L. and Taraxacum mongolicum against pathogenic bacteria of cow mastitis. Intern J Appl Res Vet Med, 12(3), 210-213.

Pereira, A. S., Shitsuka, D. M., Parreira, F. J., \& Shitsuka, R. (2018). Metodologia da pesquisa científica. UFSM.

Pinto, N. C. C., Silva, J. B., Menegati, L. M., Guedes, M. C. M. R., Marques, L. B., Silva, T. P., Melo, R. C. N., Souza-Fagundes, E. M., Salvador, M. J., Scio, E., \& Fabri, R. L. (2017). Cytotoxicity and bacterial membrane destabilization induced by Annona squamosa L. extracts. An Acad Bras Cienc, 89(3), $2053-2073$.

Saha, S. K., Saha, S., Hossain, M. A., \& Paul, S. K. (2015). In vitro assessment of antibacterial effect of garlic (Allium sativum) extracts on Pseudomonas aeruginosa. Mymensingh Med J, 24, 222-232.

Samani, B. H., Zareiforoush, H., Lorigooini, Z., Ghobadian, B., Rostami, S., \& Fayyazi, E. (2016). Ultrasonic-assisted production of biodiesel from Pistacia atlantica Desf oil. Fuel, 168, 22-26.

Santos, L. M., Stanisic, D., Menezes, U. J., Mendonça, M. A., Barral, T. D., Seyffert, N., Azevedo V., Durán N., Meyer R., Tasic L., \& Portela, R. W. (2019). Biogenic silver nanoparticles as a post-surgical treatment for Corynebacterium pseudotuberculosis infection in small ruminants. Front microbiol, $10,1-11$.

Silva, F. R., Antunes, R. M. P., \& Catão, R. M. R. (2011). Avaliação da atividade antibacteriana de extratos de Annona muricata L. (Annonaceae). Biofar, 6, 27-36.

Silva, V. D. A., Silva, A. M. M., Silva, J. H. C., \& Costa, S. L. (2018). Neurotoxicity of Prosopis juliflora: from natural poisoning to mechanism of action of its piperidine alkaloids. Neurotox Res, 34(4), 878-888.

Success, O. B., Harriet, U., Mathew, B., \& Nandita, D. (2017). Studies on antibacterial spectrum of extracts of stem bark of Azadirachta indica A. Juss on some clinical isolates associated with urinary tract infection. J Bacteriol Res, 9(6), 37-43. 